\title{
Collective concept formation in educational management: An intervention study in São Paulo, Brazil
}

\author{
Monica Ferreira Lemos ${ }^{\text {a1 }}$, Yrjö Engeström ${ }^{\mathrm{a}}$ \\ ${ }^{a}$ Faculty of Educational Sciences, Center for Research on Activity, \\ Development and Learning CRADLE, University of Helsinki
}

\begin{abstract}
The purpose of this paper is to analyze how a new concept of educational management was produced in a formative intervention project for manager educators in the city of São Paulo, Brazil. Drawing on Vygotsky and Leontiev, we asked: What is the nature of the interplay between participants' personal senses and the societal meaning of educational management in the process of collective concept formation? The collective concept formation discourse was analyzed in three steps: initial explication of a raw object, clashes in further elaboration of the raw object, and stabilization of the new concept. The raw object reproduced a taken-for-granted meaning of educational management as promoting conditions for teaching and learning. The clashes occurred mainly between the notion of management for teaching and learning and the notion of management for teaching and learning for community transformation. The stabilization was achieved by a vote and defined the purpose of educational management seemingly as it was already formulated in the raw object. However, this stabilization was temporary and involved attempts to transcend the opposition between the two alternative definitions. Thus, the actual meaning and concept of educational management remained open to further steps. In this paper, we report on how manager educators engage in a collective effort to conceptualize educational management. Our article proposes and tests a new theoretical framework for studying changes in educational management as processes of collective concept formation.
\end{abstract}

Keywords: concept formation, educational management, sense, meaning, object, clash, stabilization

CRADLE, University of Helsinki, P.O. Box 9, Siltavuorenpenger 1A, FI-00014, Finland; monica.lemos@helsinki.fi 


\section{Introduction}

Educational managers need to grapple with alternative concepts and shape their shared conceptual orientation in the face of societal pressures demanding improvement and change in schools. In other words, educational managers are involved in efforts of collective concept formation. Research on concept formation has been dominated by laboratory and classroom studies of what Greeno (2012) calls "formal concepts," that is, concepts that use formal logic or mathematics to derive implications of assertions. Greeno (2012) suggests that the study of concept formation should be expanded to functional concepts, which have meanings in activities and contribute to the ways in which participants organize their understandings of what they are doing. This expansion opens up the field of "concept formation in the wild" (Engeström \& Sannino, 2012).

In studies of organizational change, notions such as "interpretive scheme" (Bartunek, 1984) and "shared frame" (Orlikowski \& Gash, 1994) have been used to denote what we call functional concepts. Some studies of the formation of organizational categories also come close to a similar understanding.

Categories are not simply labels that actors use to sort out social phenomena into appropriate bins but are instead associated with actors' status, interests, and identities [...]. They exemplify what is socially valued through rewards and penalties $[\ldots]$, reveal boundaries that demarcate who and what is included or excluded within a category [...], and often spark conflict over category definition and content." (Jones, Maoret, Massa, \& Svejenova, 2012, p. 1524)

Bartunek (1984) points out that major changes in organizations occur through a dialectical interplay of old and new interpretive schemes or ways of conceptualizing the organization. Thus, any significant organizational transformation is inevitably also a process of collective concept formation. "When practices change, concepts also change" (Hutchins, 2012, p. 315). This becomes particularly important when we are concerned with a change from top-down management to some form of participatory management. To succeed such a transformation requires a qualitative shift in the ways in which practitioners perceive and think about management. Thus, it is crucial to understand how those who are involved in the organizational change actually conceptualize the new system, in this case, the emerging system of educational management. While the formation of a new concept is in itself not a guarantee of corresponding change in practice, it is a necessary component of such a transformation.

Reforms aimed at participatory educational management often remain superficial and ineffective (Anderson, 1998). To overcome top-down 
models of educational management, Lumby (2012) and Bush (2014) propose culture as a key mediator of power within organizations. Mueller (2013) proposes a theoretical conceptualization of organizational values. Moreover, Hatzoupoulus, Kollias and Kikis-Papadakis (2015) observe that the understanding of educational management and leadership can shape the development of school leadership. These efforts exemplify an ongoing search for innovative theoretical approaches that would integrate the perspective of the participants and the perspective of the larger system in studies of educational management and leadership. In line with this general pursuit, we see concept formation as a dynamic interplay between personal sense and societal meaning. We put forward the notion of collective concept formation as a complementary lens that may enrich this endeavor of theoretical revitalization of the field of educational management.

The objective of this paper is to analyze how a new concept of educational management was produced in a formative intervention project for educational managers in the city of São Paulo, Brazil. The Management in Creative Chains project, led by Professor Fernanda Liberali from 2011 to 2015, was initiated to deal with the lack of collaboration amongst educational managers representing different levels of administration. Such lack of collaboration was hampering the implementation of development policies and participatory decision-making in the school system (Liberali, 2012). To overcome the lack of collaboration, the first task of the project was to generate a shared concept of educational management that would correspond to the educational managers' needs. Thus, the concept produced would have to take into consideration different voices involved in the city educational management process at different levels: Municipal Secretariat of Education, Regional Boards of Education, and schools.

In this paper, we investigate the process of concept formation in educational management at the level of a Regional Board of Education. We focus on the formation of a concept of educational management in collective discussion and debate. Our basic assumption is that concepts constructed in collective activity offer new possibilities for the transformation of educational management in material practice. In other words, collective practice-bound concepts are consequential for the shaping of the future.

Seen in this light, collective concept formation is a crucial element in the transformation of educational management that builds on active participation and commitment of practitioners. Collective concept formation is not a linear process of acquisition of prescribed meanings. It is typically a spiraling process of struggle and debate between alternative interpretations and standpoints. This can lead to the formation of a new, richer meaning, as exemplified in a recent analysis of the notion of school autonomy as a dialectical interplay 
between decentralization and centralization (Toh, Hung, Chua, He, \& Jamaludin, 2016).

The main question that guides this study is: How does collective concept formation happen among educational managers involved in a major effort to reorganize the management of their educational system? More specifically, drawing on Vygotsky (1987) and Leontiev (1978), we asked: What is the nature of the interplay between the participants' personal senses and the societal meaning of educational management in the process of collective concept formation?

In the next section, we give a brief overview of the history of educational management in São Paulo. This section is followed by our theoretical framework, focused on the interplay between sense, meaning, and concept. After that, we describe the organizational context of our study, including the overall process of the intervention in which the concept formation effort is embedded. We will then specify the data and methods used in the analysis. The actual analysis focuses on a meeting which we examine in three sections: an overview of the meeting, an analysis of the main positions taken in the debate, and an analysis of the closure and stabilization of the concept constructed. The article ends with a discussion on the implications of the findings for the transformation of educational management.

\section{Historicizing educational management in São Paulo}

According to the Memorial of Municipal Education (SME, 1995) public education in the city of São Paulo started in 1935 with Children's Clubs. The Clubs were created by the Brazilian poet and educator Mário de Andrade, although non-scholarly, these spaces were considered the first public spaces for education in the country (De Faria, 1999). Children from three to twelve years old were able to attend the Children's Club to practice sport and to be involved in artistic tasks. In the fifties, only Brazilian citizens could attend school and the gymnasium had an admission test.

From 1964 to 1985, the Brazilian political situation changed due to the military government. According to Godoy (2011), the main emphasis was on a cohesive and uniform primary educational system, which would ensure that people would be able to read and follow the regulations established by the military government. In 1971 the division into primary and secondary education was abolished and students were able to finish their basic education in eight years. Godoy (2011) also points out that pedagogical concerns were replaced by administrative issues due to the creation of a system that received students from very diverse backgrounds. The diversity was generated by the opening 
of the public school to everyone, although school was still considered to be an apparatus for transmitting the military's dominant position in the state.

After the military regime, Paulo Freire became the Secretary of Education in the city. This was a remarkable event for the city for two reasons. First, he represented the first chosen appointment made by a mayor who was elected by the population. Secondly, but not less importantly, Freire was one of the most recognized pedagogues connected to progressive causes, such as critical pedagogy. His biggest challenge was to establish teaching that promoted emancipation in a contemporary metropolis.

In the nineties, educational management shifted to a Total Quality Management (TQM) perspective borrowed from the corporate world. Quality became a way of looking at school as a company and at the community as clients who were supposed to receive educational services based on evaluation of results and quantitative indicators. Instead of investments in educational programs, investments went towards teaching, recycling and building schools quickly; tin schools became popular because of their flexibility and ability to increase student places in municipal schools.

The public educational management scenario in São Paulo still largely relies on the results of external and internal assessments. To keep students at school and reduce absenteeism, children receive free school uniforms once a year, and powder milk cans every month. These policies were adopted in the nineties, became more widespread during the 2000's and are still in place today.

The most important change in the 2000's has been the creation of the Unified Educational Centre (CEU), which coordinates the different levels of education for children, youngsters and adults, as well as organizes sports and cultural events for students and the communities. In 2004 the Municipal Secretariat of Education conducted a survey of students' literacy levels in the third grade. The results showed that $30 \%$ of the students did not know how to read or write. To deal with this issue the Municipal Secretariat of Education organized continuing teaching education, monitoring and guidelines, such as the preparation of Curricula Guidelines Programme, the main objective was to standardize the city curricula and to establish expectations for each subject area in each year of elementary education.

However, the introduction of the evaluation and monitoring processes in the educational system also one-sidedly emphasized the results of the reading and writing assessments. This led to a strong demand for reports and training focused on school outcomes and on achieving better results in the external evaluations (Liberali, Borelli, \& Lima, 2015).

The history briefly reviewed above shows how shifts in political power can influence the policies of educational management in the city, generating the necessity of rethinking educational management and moving towards a system 
in which the different practitioners of the city's educational system could work collectively to develop and implement activities. Neither the Freirean idea of popular education nor the outcomes-oriented corporate TQM model of management is sufficient in itself today. A new concept of educational management is needed. There is widespread understanding among educators that educational management needs to be thought of as something constituted and produced by people who have not merely a formal working relationship with a system but a shared responsibility for promoting human development.

\section{Theoretical framework: meaning, sense, and concept}

Meaning-making and meaningful learning are frequently used as key notions in educational research (e.g., Ignelzi, 2000; Lantz-Andersson, Linderoth, \& Säljö, 2009; Scott, 1998). On the other hand, Weick's (1995; 2001) notion of sense-making is prominent and widely used in organizational research. The notions of meaning-making and sense-making are usually not related to one another in any explicit way, in fact, they are often used interchangeably. This stance entails loss of analytical power. Thus, we build our analysis on Leontiev's (1978) seminal work that distinguishes between personal sense and societal meaning and relates them to one another.

Meanings are produced by society and have their history in the development of language as it has historically expressed the development of material production, science, arts and ideological notions of society. Socially developed methods of action, "transformed and hidden in the material of language" (Leontiev, 1978, p. 12) are hidden behind linguistic meanings. Meanings are the most important shapers of human consciousness. However, consciousness cannot be reduced to the functioning of meanings learned from the outside. As Leontiev (1978) points out, "socially developed meanings begin to live in the consciousness of individuals as if with a double life" (p. 15). Personal sense is always a sense of something; it connects the subjects with the reality of their own life. Personal senses take shape in the lives and activities of concrete human beings; thus, personal sense creates the partiality of human consciousness. The paradox is that societal meanings can only live and develop in the form of personal senses.

Meanings are contested, not uniform or monolithic. They penetrate the individual's connections with other people. Thus, choice of meaning is also a choice between alternative or colliding social positions and interests.

Concepts stand in the middle, between sense and meaning, between processes of internalization and externalization (Figure 1). A novel collective concept is formed in an externalization movement in which personal senses are publicly 
explicated and transformed into shared societal meaning. This process necessarily also involves sub-processes of internalization, in which existing meanings are appropriated, questioned, transformed or rejected by the participants. As the novel concept emerges and becomes stabilized, it needs to be internalized, to be fully grasped, tested and put into use.

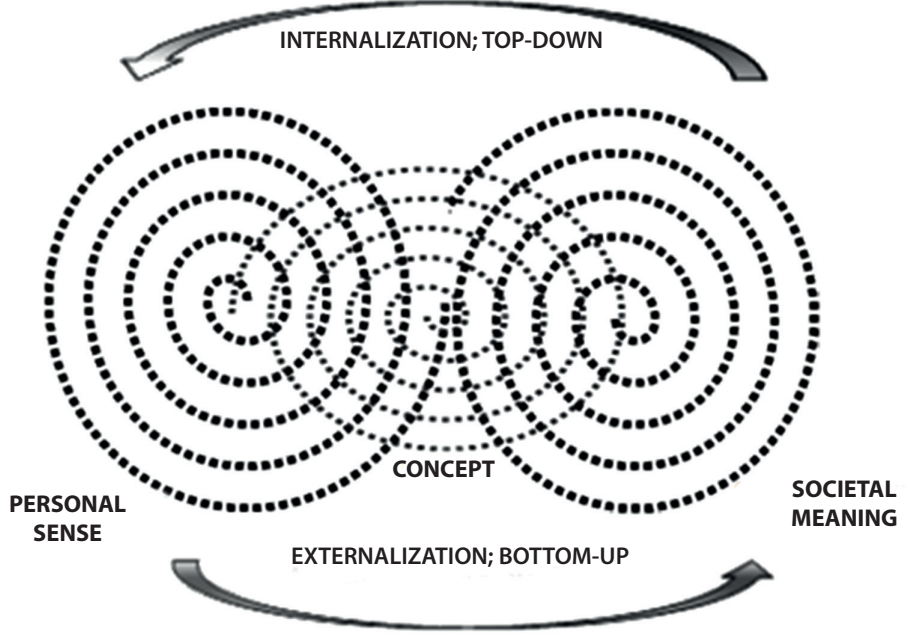

Figure 1. Interplay between sense, meaning, and concept

In a discursive process of concept formation, the societal meaning of an issue or phenomenon first appears to the subjects as a problematic raw object, a preliminary definition that needs to be interpreted and turned into a personal sense. The personal senses of different subjects typically differ from, and clash with each other. The emerging concept accomplishes a temporary resolution of the clashes; a partial stabilization of the meaning.

According to Smith (1998), we understand the raw object as a preliminary or tentative definition of the issue at hand. As we are working with concept formation in educational management, the raw object consists of participants' initial articulations of what management was for. These initial articulations typically tended to reproduce common textbook-like definitions of educational management.

We observed that as the participants worked out and discussed their own standpoints concerning the purpose of educational management, their personal senses began to emerge as different and partially clashing positions. In such a discursive process, clashes refer to opposite senses or points of disagreement. Clashes may appear as direct conflicts or disputes between two or more specific speakers (Grimshaw, 1990), but they may also be expressed as disagreements which are not directed at any specific interlocutor. 
As Smith (1998) points out, a clash can seem paralyzing. However, clashes are also a resource in that they destabilize taken-for-granted meanings and show that the raw object is not adequate but needs to be worked on. Clashes demand that inadequate ideas are examined and developed further to become closer to the adequate.

Finally, stabilization implies the resolution of clashes. To create a shared meaning is to stabilize an idea or definition. When an idea is stabilized, personal senses are transformed into shared meanings. It is important to point out that stabilization is different from conclusion. Conclusions in Toulmin's (2003) perspective happen because the arguments are justified and accepted. Stabilization, on the other hand, is a temporary accomplishment which carries future clashes and destabilization within it (Smith, 1998). Authoritative and formal procedures of stabilization such as voting tend to be particularly temporary and fragile, as they seldom reflect the deeper commitment among the participants.

\section{The organizational context of the study}

The Brazilian Educational Guidelines (Brasil, 1996) state that the public educational system is to be organized on three levels: the federal, state and municipal. In the city of São Paulo, the municipal level is further layered as depicted in Figure 2. The city Secretariat of Education is in charge of establishing rules and regulations for education at the municipal level. The Regional Boards of Education are in charge of disseminating Secretariat's decisions and organizing teaching education programmes for educational managers and teachers at the district level. Schools are responsible for the actual teaching and learning processes.

The educational system described in figure 2 comprises different educational managers with different positions mainly: secretary of education, director of elementary high school and pedagogical team at the Municipal Secretariat of Education (MSE) level; director; pedagogical director, supervisor and teacher educator at the Regional Boards of Education (RBE) level; and principal, principal assistant, pedagogical coordinator at the school level.

Apart from the secretary of education, who is invited by the mayor, the other educational managers become part of the educational system by passing a municipal public contest examination. Yet, there are managerial positions filled by public trusts appointment and by municipal public contest examinations. To sum up, all managers need to have a degree in the educational field apart from the secretary of education. In the period of this research the secretary of education had a masters' degree in public administration. 


\begin{tabular}{|c|c|c|}
\hline \multirow{3}{*}{$\begin{array}{l}\text { MUNICIPAL } \\
\text { SECRETARIAT } \\
\text { OF EDUCATION }\end{array}$} & \multicolumn{2}{|c|}{ SECRETARIAT OF EDUCATION } \\
\hline & Secretary of education & Mayor's invitation \\
\hline & \multicolumn{2}{|c|}{ Division of Technical Guidelines of Elementary ond High School } \\
\hline & Director of elementary and high school & Public trust appointment \\
\hline & Pedagogical team & Public trust appointment \\
\hline \multirow{4}{*}{$\begin{array}{c}13 \text { REGIONAL } \\
\text { BOARDS } \\
\text { OF EDUCATION }\end{array}$} & \multicolumn{2}{|c|}{ REGIONAL BOARDS OF EDUCATION } \\
\hline & Director & Public trust appointment \\
\hline & \multicolumn{2}{|c|}{ Division of Technical Guidelines-Pedagogical } \\
\hline & Pedagogical director & Public trust appointment \\
\hline \multirow{6}{*}{$\begin{array}{c}2497 \\
\text { SCHOOLS }\end{array}$} & Supervisor & Public contest examination \\
\hline & Teacher educator & Public trust appointment \\
\hline & \multicolumn{2}{|l|}{ SCHOOL } \\
\hline & Principal & Public contest examination \\
\hline & Principal assistant & Public contest examination \\
\hline & Pedagogical coordinator & Public contest examination \\
\hline
\end{tabular}

Figure 2. Levels in São Paulo city educational system and its subjects

Although the three levels of the educational system are subdivided, managers directly involved in the process of concept formation analyzed in this paper are: Pedagogical Directors and Teacher Educators on the Regional Board of Education, and the Pedagogical Coordinators in schools. The pedagogical director manages teacher educators who, in turn provide training for pedagogical coordinators and teachers from schools managed by the different Regional Boards of Education. At the school level the pedagogical coordinator is in charge of working with the needs of teacher education, students and parents.

We focus on the Regional Board of Education because the subjects who work on the concept of management are related to both the Municipal Secretariat of Education and to the schools.

\section{Data}

The data in this paper originates from the project "Management in Creative Chains" (Liberali, 2012), during which researchers collected data by observing, taking notes and video-recording the formative meetings in collaboration with educational managers. Such formative meetings lasted four hours each session and happened monthly in 2011 and 2012. 
First, educational managers produced a collective definition of management, bearing in mind the specificities of their contexts and the relation to other levels of the educational system. Second, to reorganize their activities, the educational managers implemented a tool called management plan, which represented different activities developed by educational managers. Finally, the educational managers described each activity that they identified by defining its interrelated elements by means of the activity system model.

In this article we focus on the interplay between sense and meaning, and the first phase of the project is towards the concept formation in educational management. To do so, we examine two videotaped meetings devoted to the conceptualization of educational management in one of the 13 Regional Boards of Education. We briefly describe the first meeting as necessary background; our detailed analysis is focused on the second meeting, which has been transcribed and subsequently translated from Brazilian Portuguese to English. The translation was made by the first author, from whom a copy of the original transcription may be obtained if needed.

The first meeting took place on 12 August 2011 and lasted four hours and $20 \mathrm{~min}$. Attended by approximately 30 Pedagogical Coordinators (PCs) from different schools managed by the RBE, four teacher educators, the pedagogical director, the consultant researcher and a researcher. During the meeting, one hour and 50 min were devoted to the discussion aimed at explicating a shared meaning of educational management. The consultant researcher (CR) introduced definitions by different authors who study management, so they could compare their definition with the authors' definitions.

First, the CR asked the PCs to complete a list fill out a table of guiding questions, produced by the consultant researcher to organize the discussion. Each group was in charge of one question.

Table 1. Guiding questions for concept formation

\begin{tabular}{l|l}
\hline Question & Content \\
\hline WHAT? & The core words that explain the meaning \\
\hline WHAT FOR? & Management motives \\
\hline WHY? & Management reasons or needs \\
\hline HOW? & Mediating instruments of management \\
\hline
\end{tabular}


Each group presented its answer. The consultant researcher then opened to the floor by stating that her proposal was to make a critical construction of the concept. She emphasized that she was not going to give PCs a closed definition, but they had to build that together.

The second meeting happened on 23 September 2011 and lasted four hours. There were 45 participants: the pedagogical manager $(M)$, three teacher educators (TEs), around 39 pedagogical coordinators (PCs), the consultant researcher (CR) and one researcher (R). The pedagogical manager and the teacher educators observed the discussion, the consultant researcher guided the discussion, the researcher took notes of the definitions during the discussions and the pedagogical coordinators discussed the definition of educational management. Table 2 depicts the flow of thematic contents in the second meeting, which is the main focus of our analysis.

Table 2. Flow of thematic contents at the focal meeting

\begin{tabular}{|c|c|c|}
\hline Turns & $\begin{array}{c}\text { Turn } \\
\text { initiator }\end{array}$ & Content \\
\hline $174-176$ & CR & What for: reading. \\
\hline $177-180$ & PC9 & Working conditions. \\
\hline 181 & PC10 & Teaching and learning conditions. \\
\hline $182-193$ & CR & $\begin{array}{l}\text { One thing is to transform one condition of teaching and learning. } \\
\text { Another one is to think about the conditions for teaching and learning. }\end{array}$ \\
\hline 194-196 & CR & $\begin{array}{l}\text { My position: To promote communities' transformation where schools } \\
\text { are. }\end{array}$ \\
\hline 197-207 & PC12 & Political moment: "what for" is to achieve goals. Results percentage. \\
\hline $208-217$ & PC7 & $\begin{array}{l}\text { Dialogue concerning society school and school society is } \\
\text { unavoidable. }\end{array}$ \\
\hline $218-222$ & CR & Relations between learning activities and day-to-day life. \\
\hline $223-236$ & PC14 & $\begin{array}{l}\text { Relations between school society and demand from society over } \\
\text { school. }\end{array}$ \\
\hline $237-244$ & PC5 & More concern with teaching and learning than transformation. \\
\hline $244-266$ & PC16 & People who are involved in the management process \\
\hline $267-274$ & PC3 & It is too technical. Concern about administrative resources. \\
\hline $275-285$ & PC13 & Need to be committed and to commit others. \\
\hline $286-290$ & CR & $\begin{array}{l}\text { Definition of criteria to evaluate the management plan and the } \\
\text { activities to be developed at school. }\end{array}$ \\
\hline
\end{tabular}




\begin{tabular}{lcl}
\hline Turns & $\begin{array}{c}\text { Turn } \\
\text { initiator }\end{array}$ & Content \\
\hline 291-298 & PC5 & Debate teaching, learning and society or community transformation. \\
\hline 299-309 & PC13 & Discussion about school pedagogical project. \\
\hline $310-312$ & CR & Need to take decision. Vote. \\
\hline $313-330$ & PC13 & $\begin{array}{l}\text { Project about racism at school. } \\
\text { Project versus commitment. }\end{array}$ \\
\hline $331-336$ & PC17 & $\begin{array}{l}\text { Student rescue. Make student take at least stationary material to } \\
\text { school. }\end{array}$ \\
\hline 337 & CR & Need to take decision. Vote. \\
\hline $338-342$ & PC18 & $\begin{array}{l}\text { Transformation. Example of a dirty stream close to school. } \\
\text { Management to make people's lives better. }\end{array}$ \\
\hline 343 & CR & $\begin{array}{l}\text { Commitment. Commitment beyond salaries. It is not a drawback if } \\
\text { transformation is not possible at this historical moment. }\end{array}$ \\
\hline $344-360$ & PC7 & $\begin{array}{l}\text { Transformation as an issue. If not for transformation. What is the } \\
\text { function of a school? }\end{array}$ \\
\hline $361-370$ & CR & \begin{tabular}{l} 
Voting. \\
\hline 0
\end{tabular}
\end{tabular}

Note. CR - Consultant Researcher; PC - Pedagogical Coordinator.

\section{Method of analysis}

We use three categories as devices to analyze data from the point of view of the interplay between personal sense and societal meaning. These categories are (1) raw object, (2) clash and (3) stabilization.

The first analytical category, the raw object, consists of participants' preliminary definitions of what educational management was for. As pointed out above, this was a broad and unelaborated notion generated by the participants in groups at the first meeting. The raw object may be regarded as an articulation of the commonly accepted or taken-for-granted societal meaning of educational management.

The second analytical category, clash, refers to opposite senses or points of disagreement. Typically clashes involve personally charged negatives such as "I don't think" or "it is not so" and expressions of uncertainty or hesitation such as "I am not sure." Clashes represent tensions and conflicts between different personal senses put forward by the participants. Clashes may be included also in the discourse of a single participant, indicating dilemmas and conflicts within the personal sense of a subject. 
The third analytical category, stabilization, corresponds to a partial or full resolution of the clashes. This may be accomplished by means of tacitly emerging or an explicitly negotiated consensus, voting, or decision by an authority. In stabilization, personal senses are transformed into a shared meaning. In the case analyzed here, stabilization took place when the participants made a decision concerning the definition of what educational management represents.

The three analytical categories described above are used as interpretive lenses in a stepwise manner, as reported in the next three sections.

\section{First step of analysis: The raw object}

The raw object in this case was the broad definition of educational management as discussed by the groups during the first meeting. Although each definition was produced by one group, the other groups were supposed to take notes of possible questions and comments. The definitions below refer to the summary of the contents produced by the groups in meeting one. The raw object was then to be further debated and negotiated to shape a more stable meaning to educational management.

WHAT? - Set of actions for the organization of resources and instruments collaborating in a productive way to support a common aim or aims.

A set of action is understood as planning the use of financial and human resources; and distribution, systematization, standardization, articulation, evaluation, management, amongst others.

WHAT FOR? - Focus on educational management. To promote conditions so that the process of teaching and learning of concepts, procedures, and attitudes happens bearing in mind all the actors involved at school.

WHY? - Because the actors come from different cultural backgrounds. When we refer to actors, we mean principals, teachers, students, students' parents, assistants and staff. Their realities are diverse as well as their conceptions of education, clientele, and value formation. In the end each actor contributes with their own singular way of management formation. Management differs from one school to another.

HOW? - By listening; dialoguing dialectically defining and achieving institutional goals, in an institutional self-critical way, raising priorities, managing time, and administrating physical, material and human resources.

By dialoguing dialectically, Hegelian dialectics, we understand that the institution dialogues, debates and positions. It is not only a matter of listening, taking notes and agreeing. 
When referring to goals, we are not referring to individual goals. The goals are focused on the school's aims.

Priority is a key word in the group and it should be considered according to the institution's aims.

These initial definitions were discussed, problematized and developed further in the second meeting with the support of the four guiding questions. Our analysis focuses on the second question: What for? As shown in Table 3, this question generated the largest number of turns of talking in the discussion.

Table 3. Duration and turns of talking devoted to the guiding questions in the second meeting

\begin{tabular}{llcc}
\hline Question & Content & Duration & Turns \\
\hline WHAT? & The core words that explain the meaning & $40 \mathrm{~min}$ & 84 \\
\hline WHAT FOR? & Management motives & $1 \mathrm{~h}: 49 \mathrm{~min}$ & 191 \\
\hline WHY? & Management reasons or needs & $5 \mathrm{~min}$ & 18 \\
\hline HOW? & Mediating instruments of management & $3 \mathrm{~min}$ & 16 \\
\hline
\end{tabular}

In the second meeting, the consultant researcher (CR) initiated the discussion of What for? by reading what had been produced in the previous meeting: "Focus on educational management. To promote conditions so that the teaching and learning process of concepts, procedures, and attitudes happen bearing in mind all the actors involved at school."

A pedagogical coordinator (PC9) pointed out that among the many things included in what management was for, not only teaching-learning but also the promotion of working conditions for teaching and learning needed attention. The CR asked if there was anything else and attempted to close the definition. However, this attempt was interrupted when PC10 stated in a hesitating manner: "I don't know... I would perhaps withdraw to promote conditions of teaching and learning of all actors." This indicated that the concept of educational management was not yet ready to be closed and stabilized. In fact, this episode worked as a trigger that opened up clashes related to what educational management was for.

\section{Second step of analysis: Clashes}

In the transcript of the second meeting, we identified 12 clashes, summarized in Table 4. 
Table 4. Summary of clashes

\begin{tabular}{|c|c|}
\hline Turn & Clash contents \\
\hline $184-196$ & $\begin{array}{l}\text { 1. Generation of teaching and learning vs. generation of teaching and } \\
\text { learning for community transformation }\end{array}$ \\
\hline $197-205$ & $\begin{array}{l}\text { 2. Goal achievement (referring to assessment numbers) vs. transformation of } \\
\text { community }\end{array}$ \\
\hline $207-215$ & $\begin{array}{l}\text { 3. Relation between school and society vs. intentionality behind what is } \\
\text { done in the classroom to change people's lives }\end{array}$ \\
\hline $218-220$ & $\begin{array}{l}\text { 4. Commitment to teaching and learning for community transformation } \\
\text { in words vs. commitment to teaching and learning for community } \\
\text { transformation in school actions }\end{array}$ \\
\hline $221-236$ & $\begin{array}{l}\text { 5. Transformation doesn't come from school vs. interaction between school } \\
\text { and community for transformation }\end{array}$ \\
\hline $237-244$ & $\begin{array}{l}\text { 6. Teaching and learning } v s \text {. teaching and learning for community } \\
\text { transformation }\end{array}$ \\
\hline $267-282$ & 7. Administration of resources vs. political positioning of transformation \\
\hline $283-290$ & 8. Administration of resources vs. promotion of community transformation \\
\hline $290-298$ & 9. Accomplishment of policies vs. transformation of the community \\
\hline $315-330$ & $\begin{array}{l}\text { 10. Project based on teaching vs. classroom activities connected to } \\
\text { community transformation }\end{array}$ \\
\hline $331-346$ & $\begin{array}{l}\text { 11. Rescue of school function by working with knowledge vs. improvement of } \\
\text { school by transforming the community }\end{array}$ \\
\hline $347-360$ & $\begin{array}{l}\text { 12. Teaching and learning of concepts vs. teaching and learning of contents } \\
\text { and concepts to transform community }\end{array}$ \\
\hline
\end{tabular}

The most prominent tension behind the clashes was that between two main positions of what management was for: teaching and learning versus teaching and learning for community transformation. This tension could be seen particularly clearly in clashes $1,2,6,10,11$ and 12 , and it was indirectly or partially present in practically all clashes.

By asking the controversial question "What is the management going to generate?" the CR triggered a discussion on whether educational management was for teaching and learning per se or for teaching and learning that was going to generate something else in terms of community transformation.

We examined more closely three out of the 12 clashes, namely clashes 1 , 7 and 11 . Table 5 summarizes the key arguments presented for the two main positions in these three clashes. 
Table 5. Main arguments in three clashes

\begin{tabular}{lll}
\hline Clash & $\begin{array}{l}\text { Teaching and learning } \\
\text { 191 PC7: The main aim is } \\
\text { teaching and learning. To } \\
\text { achieve goals (referring to } \\
\text { assessments). }\end{array}$ & $\begin{array}{l}\text { Community transformation } \\
\text { this. It is to generate transformation. But this } \\
\text { is why I think management generates } \\
\text { teaching-learning, that generates } \\
\text { transformation. This is how I understand it. } \\
\text { You don't necessarily have to agree with this. }\end{array}$ \\
\hline 7 & $\begin{array}{l}\text { 267 PC3: But I agree with you } \\
\text { that the way we put it is very } \\
\text { technical when we consider the } \\
\text { percentage of goals we have to } \\
\text { achieve. }\end{array}$ & $\begin{array}{l}\text { 277 PC13: Because, when I talk about } \\
\text { transformation I do not want to take the } \\
\text { yourning into a totalitarian society, } \\
\text { solidarity, citizenship, and autonomy. } \\
\text { So I think we have to get committed. }\end{array}$ \\
\hline $\begin{array}{l}\text { 333 PC18: (...) The fight now } \\
\text { is to regain some values ... the } \\
\text { primary function of school, } \\
\text { which is not the only one, but } \\
\text { the essential one, which is to } \\
\text { work with knowledge! }\end{array}$ & $\begin{array}{l}\text { 338 PC17: To me if teaching-learning } \\
\text { does not make my life better, as a person, } \\
\text { as a human being or as pedagogical } \\
\text { coordinator, it has no meaning to me. }\end{array}$ \\
\hline
\end{tabular}

Note. CR - Consultant Researcher; PC - Pedagogical Coordinator.

In Clash 1, PC7 defined the purpose of educational management as serving teaching and learning to achieve curricular goals. CR argued that teaching and learning and community transformation were intertwined: "management generates teaching-learning, that generates transformation." This provoked a dilemma, prompting educational managers to present examples of situations in which they believed they were working with management for community transformation on one hand, and raising the voices of those who believed they needed to concentrate on teaching and learning on the other hand.

Also in Clash 7, PC3 pointed out that focusing on percentages of assessed goal achievement is indeed technical, yet necessarily foundational in educational management. PC13 brought the argumentation to a more intense and political level, emphasizing "exercise of solidarity, citizenship, and autonomy" and concluding that "we have to get committed." The clash began to emerge as a conflict between a technical and a political orientation to educational management.

In Clash 11, we witness an escalation and intensification of the argumentation. PC18 initiated discussion on rescuing the school by using politically colored language "The fight now is to regain some values..." that one would have expected from the side arguing for community transformation. She then 
used "but" as a logical connector that introduced a controversial point of view, namely that what is actually essential is "to work with knowledge!" PC18 also used other resources such as the questions "What happens?" and "How do we talk about the construction of teaching-learning process?" to catch the attention of the audience. The personal pronoun "we" and the possessive pronoun "our" were used to implicate all the participants in the discourse. PC18 also reinforced her argument by means of an example from her day-to-day school reality, stating that "The struggle is to make the kids take the notebook to school, and the backpack, so that they can do at least from time to time a piece of homework."

PC17 introduced her counter-argument by invoking living conditions in her community: "Our school has always worked with themes - and there is a polluted stream next to our school." She used the first person object pronoun "to me" and the possessive "my" to emphasize that she was introducing a very personal point of view, different from PC18. She referred to the tours the school team made every year to be more acquainted with local problems. By doing so, PC17 implicated the school team by using the pronoun "we." At that point, she did not speak for herself anymore, she was also voicing the opinion of the school team.

With the strong sentence "Damn, I want to dream of a better school!" PC17 brought the discussion to a new level of intensity and commitment. With the statement "I deserve it, my students deserve it, you deserve a better school", she included herself, the students, and the other educational managers in a call for community transformation as the task of educational management.

Therefore, participants built the concept of educational management by means of clashing arguments. The clashes became more intense and arguments more passionate as the discussion evolved. However, there was very little direct argumentation against the opposing point of view, in the form of negations and refutations. The dominant form of argumentation was positive and affirmative, making a case for one's own point of view rather than against the other one's point of view.

\section{Third step of analysis: Stabilization}

The first attempt to close the definition was between turns 333 and 338 when the PCs were debating the two alternatives, management for teaching and learning or management for community transformation. Next, CR intervened and expressed her concern about the accomplishment of the tasks planned for the meeting that started at 9:00 am and was supposed to end at 12:00 am. 
It was 10:30 am and the group was only discussing the second item of what was supposed to be a recapitulation of the previous meeting's outcome at the beginning of the meeting. So, the CR proposed a vote as a possibility of closing the definition. After some more debate, the CR organized the voting by first asking who would vote for teaching and learning and then who would vote for community transformation.

By organizing the voting, the CR closed the discussion about what management was for. As a result, 27 educational managers voted for the management of teaching and learning, ten for the management of community transformation, and two abstained. Besides, PC15 voted for both of the two options. The final definition of the purpose of educational management was "To promote working conditions so that the process of teaching and learning of concepts, procedures, and attitudes happen bearing in mind all the actors involved at school." The participants added the word "working," otherwise the definition was the same as the one in the raw object.

In our context, there were two levels of stabilization. The first level of stabilization concerned the time constraints during the meeting demanding a closure from that moment. The second level of stabilization concerned the shared meaning of what educational management is for. Momentary intermediate stabilizations are seldom durable; they require renewed destabilization (Cussins, 1992). Thus, stabilization can be a lengthy multi-step process. In this meeting a momentary stabilization was accomplished, but the meaning of what management was for remained open. This is vividly illustrated by a remarkable moment in the voting process when one of the participants, PC15, externalized her indecision. When asked about management for teaching and learning she raised her hand - and when asked about the management of community transformation she raised her hand again. Although PC19 tried to contain PC15 by pulling her arm down, she laughed and insisted to be counted also for the management of community transformation. Figures $3 \mathrm{a}, 3 \mathrm{~b}, 3 \mathrm{c}$ and $3 \mathrm{~d}$ illustrate this moment.

The episode depicted in Figures $3 \mathrm{a}$ to $3 \mathrm{~d}$ suggests that participants were not ready for an unequivocal and permanent definition of what educational management is for. The fact that PC15 raised her hand in favor of both voting options may be interpreted as a need for searching a merger or combination of both alternative definitions. In her own way, PC15 seemed to argue that the competing definitions were not mutually exclusive but could complement one another. 


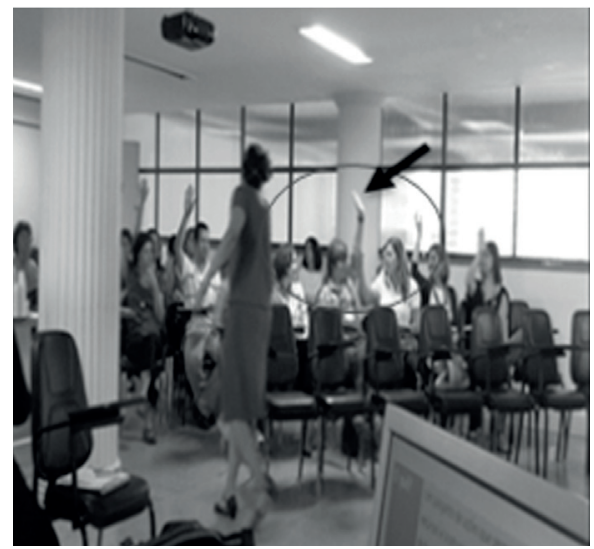

Figure 3 (a). Voting Moment

361. CR. Let's vote! First of all: those who think we should stop here as it is, raise your hand please! People, help me to count please. Pay attention to the commitment!

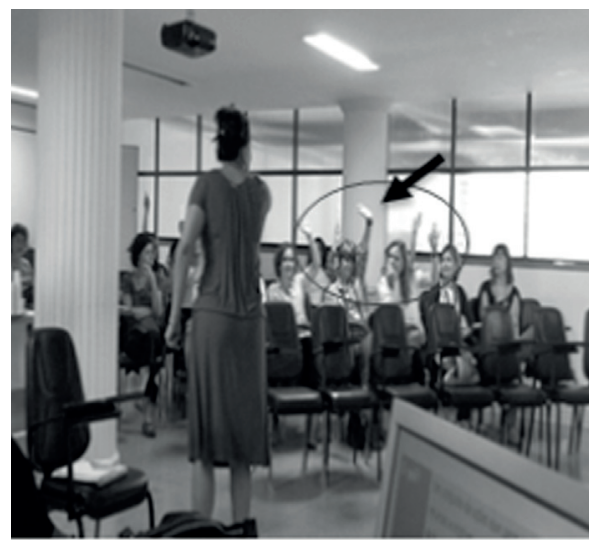

Figure 3 (c). Voting Moment 364. PC15. But I want to vote again. 365. CR. ... (counting)

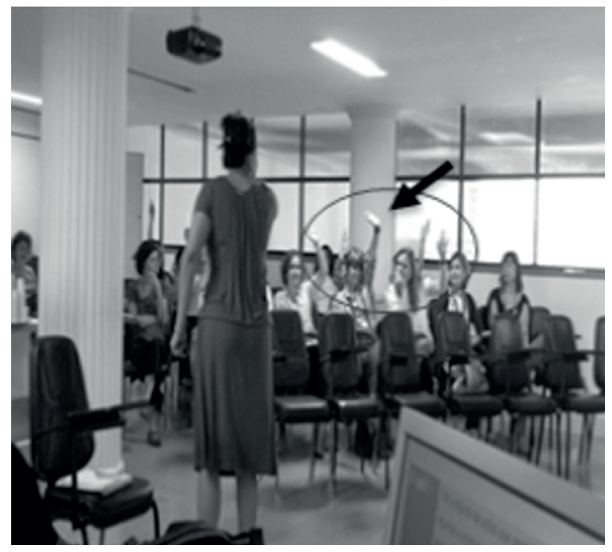

Figure 3 (b). Voting Moment

362. CR. So raise your hand if you want to add community transformation! 363. PC19. You have already raised your hand.

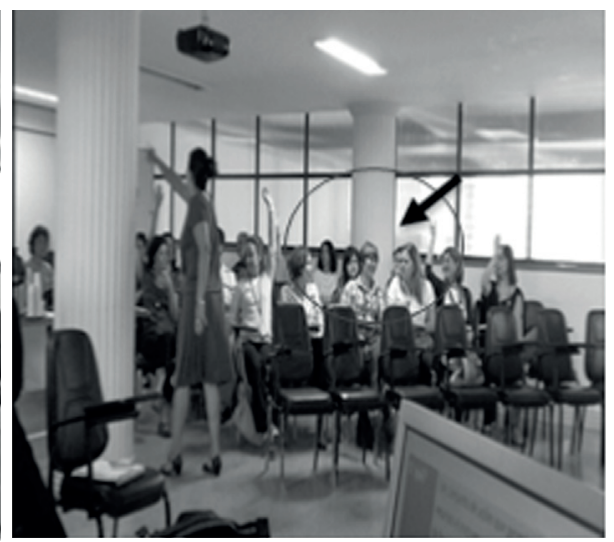

Figure 3 (d). Voting Moment 366. PC15. Count me in! 
In a previous study, such a complementarity has been discussed in terms of the emergence of a perspectival concept. Perspectival concepts embrace "the crucial importance of temporal dimension in the formulation of complex concepts" (Engeström, Pasanen, Toiviainen, \& Haavisto, 2005). A perspectival concept contains steps or successive phases in the evolution or transformation of its object. The successive phases may at the outset appear as hostile opposites or mutually exclusive alternatives. However, in a processual, historical and developmental perspective, one of the opposites may be seen as a precondition or necessary building block for the emergence of the other one. Such perspectival concepts are a demanding type of "possibility knowledge," quite different from the more common "stabilization knowledge" that operates with fixed and unchanging categories (Engeström, 2007).

Although the discussion was stabilized by the voting, the evolution of the concept was not finished. As (Smith, 1998) points out, "it is exactly by letting go while retaining appropriate directedness and orientation that the world comes into presence", the participants let it go for the time being, but they had also gained directedness and orientation that demanded moving forward.

\section{Discussion and conclusion}

The main question present throughout this study was: How does collective concept formation happen among educational managers involved in a major effort to reorganize the management of their educational system? The collective concept formation happened in three steps: initial explication of a raw object, clashes in further elaboration of the raw object, and stabilization. The raw object reproduced a taken-for-granted meaning of educational management as promoting conditions for teaching and learning. The clashes occurred mainly between the notion of the management of teaching and learning and the notion of the management of teaching and learning for community transformation. The stabilization happened by a vote and defined the purpose of educational management seemingly as it was already formulated in the raw object. However, this stabilization was temporary and involved attempts at transcending the opposition between the two alternative definitions. Thus, the actual meaning and concept of educational management remained open to further investigation.

More specifically, we asked: What is the nature of the interplay between the participants' personal senses and the societal meaning of educational management in the process of collective concept formation? Our answer to this question is summarized in Figure 4. 


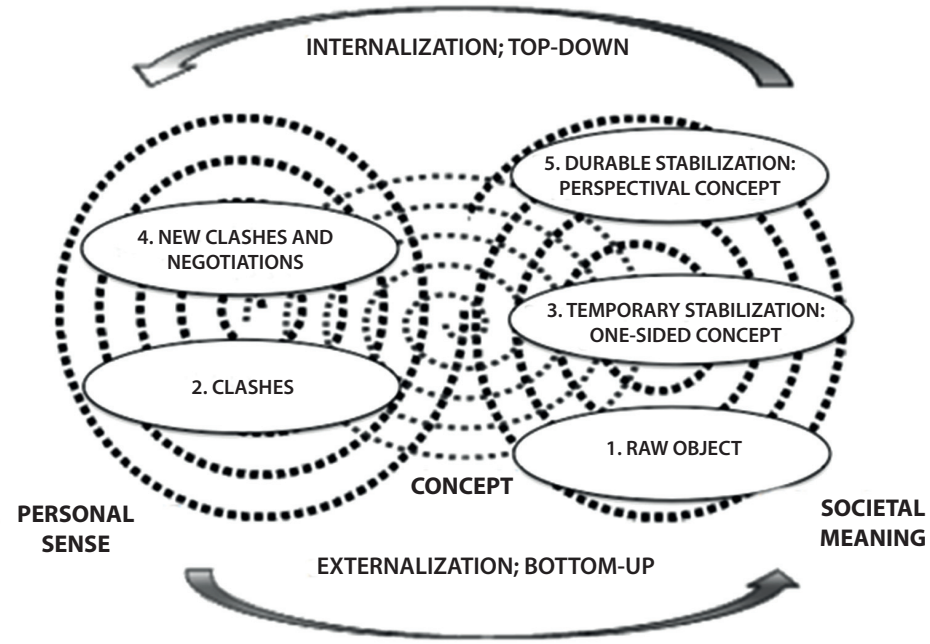

Figure 4. Enriched view of the interplay between sense, meaning, and concept

As Figure 4 shows, concept formation began with the identification or construction of a raw object. Such an initial raw object typically reproduces the commonly accepted societal meaning of the phenomenon in focus. In other words, concept formation does not start from a clean state; it must confront the existing common sense and dominant ideological representations of the phenomenon or issue in focus.

The second step in the concept formation analyzed in this paper consisted of clashes between and within the participants' personal senses related to the focal issue. We may assume that the clashes in discourse have their roots in systemic contradictions in historically formed material practices (Engeström \& Sannino, 2012). However, an analysis of such contradictions in the practices of educational management in São Paulo is beyond the scope of this article.

The third step depicted in Figure 4 is temporary stabilization of the societal meaning. In collective formation of complex concepts, there are typically multiple successive partial stabilizations that lead to one-sided conceptualizations. We predict that the process of concept formation will continue as the temporary stabilization has already been contested by PC15 at the very moment of closure by voting. Thus, Figure 4 not only summarizes our findings; it is also a pointer toward more longitudinal studies of collective concept formation processes in educational management.

In our model, collective concept formation is seen as interplay between sense and meaning, moving from a raw object to the explication of personal senses. In our data, this phase was also saturated with clashes between alternative personal senses. Furthermore, our model suggests that the collective 
eventually needs to move from clashes to at least temporary stabilization of the emerging concept.

Our three-step model is an attempt to understand the dynamics of concept formation from the point of view of interplay between sense and meaning. Other potentially powerful models of the steps of concept formation in practice include those of Davydov (1990), Engeström (2014), Hutchins (2005) and Nersessian (2008). However, none of these takes the dialectics of sense and meaning as its starting point (for an overview, see Engeström \& Sannino, 2012).

This perspective calls for more longitudinal studies of collective concept formation in educational change efforts. As direct continuation of the present study, Lemos and Liberali (in press) and Lemos Liberali and Toiviainen (in progress) analyze how educational managers plan activities based on the process of concept formation in educational management. Lemos (2017) reports on how the emerging new management concept, and plans based on it, are turned into practical local action. Such longitudinal studies might also include formative interventions, such as the Change Laboratory, that facilitate and push forward collective concept formation as an important component of transformation of practice (Sannino, Engeström, \& Lemos, 2016).

In this paper, we reported on how educational managers engage in a collective effort to conceptualize educational management. Our article proposes and tests a new theoretical framework for studying changes in educational management as processes of collective concept formation. Such processes challenge meanings that are given from top-down or taken for granted, suggesting a more participatory and reflective form of educational management in which different voices of the educational system are taken into account. Taking collective concept formation as a serious challenge may help educators to overcome the superficial rhetorics, observed by Anderson (1998), which have so often plagued participatory reforms.

\section{Acknowledgements}

We would like to express our gratitude to Professor Fernanda Liberali for her valuable insights during the research and for her paper. We also would like to thank the Class of 2012 of the Doctoral Program of Developmental Work Research and Adult Education at the University of Helsinki and the Language and Activity in Educational Contexts team at the Pontifical Catholic University of São Paulo, specially Marcia Pereira de Carvalho, Giselle Maria Magnossão Vilar de Carvalho, and Fernando Rezende da Cunha Junior for their comments at different moments during the writing of the paper. 


\section{Declaration of interest statement}

We have no conflicts of interest to disclose.

\section{Funding}

The writing of the article was partially funded by The Finnish Doctoral Program in Education and Learning (FiDPEL) and CIMO scholarship (TM-128554) to Monica Lemos and the Academy of Finland grant for the project "Concept formation and volition in collaborative work" (No. 253804, PI Yrjö Engeström).

\section{References}

Anderson, G. L. (1998). Toward authentic participation: Deconstructing the discourses of participatory reforms in education. American Educational Research Journal, 35(4), 571-603. https://doi.org/10.3102/00028312035004571

Bartunek, J. M. (1984). Changing interpretive schemes and organizational restructuring: The example of a religious order. Administrative Science Quarterly, 29(3), 355-372. https://doi.org/10.2307/2393029

Brasil, M. (1996). Leis de diretrizes e bases da educação. CULTURA, M. D. E. E. Brasil: Ministério da Educação e Cultura.

Bush, T. (2014). Emotional leadership: A viable alternative to the bureaucratic model? Educational Management Administration \& Leadership, 42(2), 163-164. https://doi.org/10.1177/1741143213512742

Cussins, A. (1992). Content, embodiment and objectivity: The theory of cognitive trails. Mind, 101(404), 651-688. https://doi.org/10.1093/mind/101.404.651

Davydov, V. V. (1990). Types of generalization in instruction: Logical and psychological problems in the structuring of school curricula. Reston: National Council of Teachers of Mathematics.

De Faria, A. L. G. (1999). As contribuição dos parques infantis de Mário de Andrade para a construção de uma pedagogia da educação infantil [The contribution of Mario de Andrade's children parks to the construction of children's education pedagogy]. Educação e Sociedade, 69, 60-91.

Engeström, Y. (2007). Putting Vygotsky to work: The change laboratory as an application of double stimulation. In H. Daniels, M. Cole, \& J. V. Wertsch (eds.), The Cambridge companion to Vygotsky (pp. 363-382). Cambridge: Cambridge University Press.

Engeström, Y. (2014). Collective concept formation as creation at work. In A. Sannino \& V. Ellis (eds.), Learning and collective creativity: Activity-theoretical and sociocultural studies (pp. 234-257). New York: Routledge.

Engeström, Y., Pasanen, A., Toiviainen, H., \& Haavisto, V. (2005). Expansive learning as collaborative concept formation at work. In K. Yamazumi, Y. Engeström, \& 
H. Daniels (eds.), New learning challenges: Going beyond the industrial age system of school and work (pp. 47-77). Osaka: Japan Kansai University Press.

Engeström, Y., \& Sannino, A. (2012). Concept formation in the wild. Mind, Culture, and Activity, 19(3), 201-206. https://doi.org/10.1080/10749039.2012.690813

Godoy, A. P. (2011). "Re-visitando" a escola e o ensino municipal de São Paulo na ditadura militar ["Revisiting" school and municipal education in São Paulo during military dictatorship]. Simpósio Nacional de História. São Paulo: ANPUH-SP.

Greeno, J. G. (2012). Concepts in activities and discourses. Mind, Culture, and Activity, 19(3), 310-313. https://doi.org/10.1080/10749039.2012.691934

Grimshaw, J. (1990). Argument structure. Cambridge: The MIT Press.

Hatzopoulus, P., Kollias, A., \& Kikis-Papadakis, K. (2015). School leadership for equity and learning and the question of school autonomy. Estonian Journal of Education, 3(3), 65-79. https://doi.org/10.12697/eha.2015.3.1.03b

Hutchins, E. (2005). Material anchors for conceptual blends. Journal of Pragmatics, 37(10), 1555-1577. https://doi.org/10.1016/j.pragma.2004.06.008

Hutchins, E. (2012). Concepts in practice as sources of order. Mind, Culture, and Activity, 19(3), 314-323. https://doi.org/10.1080/10749039.2012.694006

Ignelzi, M. (2000). Meaning-making in the learning and teaching process. New Directions for Teaching and Learning, 2000(82), 5-14. https://doi.org/10.1002/tl.8201

Jones, C., Maoret, M., Massa, F. G., \& Svejenova, S. (2012). Rebels with a cause: Formation, contestation, and expansion of the de novo category 'modern architecture', 1870-1975. Organization Science, 23(6), 1523-1545. https://doi.org/10.1287/orsc.1110.0701

Lantz-Andersson, A., Linderoth, J., \& Säljö, R. (2009). What's the problem? Meaning making and learning to do mathematical word problems in the context of digital tools. Instructional Science, 37(4), 325-343. https://doi.org/10.1007/s11251-008-9050-0

Lemos, M. (2017). Collaborative agency in educational management: A joint object for school and community transformation. Revista de Administração de Empresas, 57(6), 555-566. https://doi.org/10.1590/s0034-759020170604

Lemos, M., \& Liberali, F. (in press). The creative chain of activities: Educational management and community transformation. International Journal of Educational Management.

Lemos, M., Liberali, F., \& Toiviainen, H. (in progress). The creative chain as a possibility of overcoming educational management encapsulation.

Leontiev, A. N. (1978). Activity, consciousness and personality. Englewood Cliffs: Prentice-Hall.

Liberali, F. (2012). Gestão escolar em cadeias criativas [School management in creative chains]. Brasil: Conselho Nacional de Desenvolvimento Científico e Tecnológico.

Liberali, F., Borelli, S., \& Lima, M. E. (2015). Gestão escolar em cadeias criativas: Um processo para transformações escolares [School management in creative chains: A process for school transformation]. In K. A. Silva, M. Maristella-de-Andrade, \& C. A. P. Filho (Orgs), A formação de professores de línguas: políticas, projetos e parcerias (pp. 93-141). Campinas-SP: Pontes Editora.

Lumby, J. (2012). Leading organizational culture: Issues of power and equity. Educational Management Administration \& Leadership, 40(5), 576-591. https://doi.org/10.1177/1741143212451173 
Mueller, R. A. (2013). A general model of organizational values in educational administration. Educational Management Administration \& Leadership, 42(5), 640656. https://doi.org/10.1177/1741143213510504

Nersessian, N. J. (2008). Creating scientific concepts. Cambridge: The MIT Press.

Orlikowski, W. J., \& Gash, D. C. (1994). Technological frames: Making sense of information technology in organizations. ACM Transactions on Information Systems (TOIS), 12(2), 174-207. https://doi.org/10.1145/196734.196745

Sannino, A., Engeström, Y., \& Lemos, M. (2016). Formative interventions for expansive learning and transformative agency. Journal of the Learning Sciences, 25(4), 599-633. https://doi.org/10.1080/10508406.2016.1204547

Scott, P. (1998). Teacher talk and meaning making in science classrooms: A Vygotskian analysis and review. Studies in Science Education, 32(1), 45-80. https://doi.org/10.1080/03057269808560127

SME (1995). Memorial do Ensino Municipal [Municipal Teaching Memorial]. São Paulo: Secretaria Municipal de Educação.

Smith, B. C. (1998). On the origin of objects. Cambridge: The MIT Press.

Toh, Y., Hung, W. L. D., Chua, P. M.-H., He, S., \& Jamaludin, A. (2016). Pedagogical reforms within a centralised-decentralised system: A Singapore's perspective to diffuse 21st century learning innovations. International Journal of Educational Management, 30(7), 1247-1267. https://doi.org/10.1108/IJEM-10-2015-0147

Toulmin, S. (2003). The uses of argument. New York: Cambridge University Press.

Vygotsky, L. S. (1987). The collected works of L. S. Vygotsky. New York, London: Plenum Press.

Weick, K. E. (1995). Sensemaking in organizations. London: Sage.

Weick, K. E. (2001). Making sense of the organization. Oxford: Blackwell. 